\title{
The Students' Perception Towards English Communication Practice in Sunda Strait Traffic Separation Scheme Scenarios
}

\author{
Dyah Ratnaningsih, Dian Wahdiana, Sereati Hasugian, Jornada Putra \\ Politeknik Pelayaran Surabaya \\ Gununganyar Boulevard st. No. 1 Surabaya \\ e-mail:dyalifhana@poltekpel-sby.ac.id;dw32aip@gmail.com; sereati.hasugian@poltekpel- \\ sby.ac.id; jornada.putra@poltekpel-sby.ac.id
}

\begin{abstract}
A sufficient English communication during the sea voyage is cumpolsory to gain greater safety. Then the students in the maritime education and training must be able to perform this kind of competency before they have the voyage by practicing the communication in the bridge simulator. The aim of this study is to invesitigate the students' perception during the English communication practice using the Sunda strait traffic separation scheme scenarios. This study used quantiative approach with the questionnaire which distributed to 100 (one hundred) students majoring the Teknologi Rekayasa Pengoperasian Kapal (TROK) in Diploma IV program that the subject is concerning the nautical and ship's operations. The results showed that the students had positive perceptions on English communication practice in the Sunda strait Traffic Separation Scheme (TSS) scenarios.
\end{abstract}

Keywords: Perception, English Communication, Sunda Strait Traffic Separation Scheme, Scenario

\section{Introduction}

Students in the maritime education and training especially in Surabaya Merchant Marine Polytechnic must be able to be the professional seafarers who prioritize the safety. The concise English communication at sea will give more safety for the ships, crew, cargo and also the environment. As examples are the accidents that happened in Sunda Strait which is the busiest ferry crossing lane in Indonesia. There was a collision between Ro-ro ferry Bahuga Jaya and gas tanker Norgas Chantika On 26 ${ }^{\text {th }}$ September 2012 and on 3rd May 2014 between Ro-ro ferry Marisa Nusantara and cargo ship Qihang [7]. The collison could be prevented by using the precise English communication skills. So, for the safety of life and property at sea, each seafarer must have a broad knowledge of English and good communication skills to be able to respond as the situation demands [6]. Therefore the students of Surabaya Merchant Marine Polytechnic have to perform men competence also.

To support this concern, this study tries to find out the students' perception when they have English communication practice based on certain scenarios which are the communication between ship to VTS and ship to ship in in the Sunda strait traffic separation schem (TSS). Meanwhile, perception is interpretation of information received from a person surrounding through sense such as by seeing and hearing. The perception as the process of selecting, organizing, and translating the information into meaningful

This paper is presented in The $4^{\text {th }}$ International Conference on Maritime Education and Training 
picture of world [5]. This tment is supported by [3] explaining that "the process which we select, organize and interpret information gathered by our senses in order to understand the world around us. They also categorize the two kinds of perceptions which are external perception that occurs because of the outside stimulus from the person and self perception that the individual can realize and understand his or her surrounding and condition [3].

Furthermore, the English communication in this study is the oral one that must be performed immediately in certain situations such as ships' communication using English language. Oral communication is a skill that involves the speaker and listener in expressing their ideas while the process are related to the productive skills; speaking and listening [1].

English communication practice is very neessary for students in the maritime education and training in Indonesia since they will be the professional seafarers not only in Indonesia but also in the world. Tremendeous oceans and heavy traffic straits including the Sunda strait and Lombik strait. Therefore during their study the English communication scenarios must be conducted and the Traffic Separation Scheme (TSS) in Sunda strait is included. The Traffic Separation Scheme (TSS) is traffic-management route- system ruled by the IMO where the traffic lanes indicate the general direction of the traffic flow. IMO's responsibility for ships' routing is set forth in SOLAS Chapter V, which recognizes the Organization as the only international body for establishing such systems. Ships' routing systems contribute to safety of life at sea, safety and efficiency of navigation and/or protection of the marine environment.

\section{Research Method}

The data was collected quantitatively by using the questionnaire that investigated the students' perceptions in using the English communication when performing the passing scenario of Sunda strait TSS. The participants were one hundred students in the third semester majoring the Teknologi Rekayasa Pengoperasian Kapal (Ship Operation Technology) in Diploma IV program who must be able to produce and demonstrate the VHF communication on board. And for this study they must perform the communication based on the scenarios when a vessel passing the Sunda strait TSS.

When demonstrating the scenarios, the students have been given the prescribed ship report such as section A (Name of ship, call sign, IMO identification number), section $\mathrm{C}$ or D (position), section $\mathrm{E}$ and $\mathrm{F}$ (course and speed of ship), section $\mathrm{P}$ (hazardous cargo and class), section $\mathrm{Q}$ or $\mathrm{R}$ (any breakdown, damage and/or deficiencies affecting the structure, cargo or equipment of the ship, any circumstances affecting normal navigation defined according to SOLAS and MARPOL Coventions). The students have their own roles such as the shipmasters and officers from different ships also the VTS operators. They are requested to fill in the questionnaire after demonstrating the scenarios.

\section{Results and Analysis}

After the data was gained, as the instruments, the questionnaire result was analyzed by SPSS 22 to reveal the normality, validity, and reliability. The data had normal distribution (0.051) with $100 \%$ validity and Cronbach 's Alpha 0.675 which showed that the instrument was also reliable.

This paper is presented in The $4^{\text {th }}$ International Conference on Maritime Education and Training 
Table 1. Questionnaire indicator, statement and Likert-scale

\begin{tabular}{|c|c|c|}
\hline Indicator & Statements & Apha-numeric Likert scale \\
\hline Enjoy & $\begin{array}{l}\text { I enjoy performing English communication } \\
\text { related to the Sunda strait TSS scenario }\end{array}$ & $1-$ Not at all, 2, 3, 4- Very \\
\hline Understanding & $\begin{array}{l}\text { I understand all the English communication } \\
\text { related to the Sunda strait TSS scenario }\end{array}$ & $1-$ Not at all, 2, 3, 4-A lot \\
\hline Cooperation & $\begin{array}{l}\text { I can work together with my peer using English } \\
\text { communication related to the Sunda strait TSS } \\
\text { scenario }\end{array}$ & $1-$ Not at all, 2, 3, 4-A lot \\
\hline Improvement & $\begin{array}{l}\text { I can improve my English communication } \\
\text { skills related to the Sunda strait TSS scenario }\end{array}$ & $1-$ Not at all, 2, 3, 4-A lot \\
\hline Confidence & $\begin{array}{l}\text { I feel my confidence using English } \\
\text { communication related to the Sunda strait TSS } \\
\text { scenario }\end{array}$ & $1-$ Not at all, 2, 3, 4-Very \\
\hline
\end{tabular}

Descriptive statistics for each indicator was examined for English communication of the students after they perform the scenario when a vessel passing the Sunda strait TSS. The result of the questionnaire the first indicator showed that $80 \%$ students agreed that they enjoy very much the English communication practice, $20 \%$ agree. The second also showed that $65 \%$ students agreed that they have a lot of understanding the English communication practice, $25 \%$ agree, and $10 \%$ disagree. It meant the last $10 \%$ had not really know about the terminology used in the scenario. Then, the third indicator revelaed that that $95 \%$ students agreed that they have a lot of cooperation with their friends during the English communication practice and 5\% is agree. Next, the fourth indicator revelaed that $98 \%$ students agreed that they have a lot of improvement during the English communication practice and $2 \%$ is agree. Last, is the fifth, showed that $80 \%$ students agreed that they are very confident during the English communication practice, $12 \%$ is agree and $8 \%$ is disagree or the a little bit unconfident when performing the English communication practice.

\section{Conclusion}

English communication practice must be used and performed a lot by the students. By knowing their perceptions, the learning activities can be conducted and varied in order to achieve higher English communication skill such as the scenario in the Sunda strait Traffic Separation Scheme (TSS). As [2] supports this result for the learning activities that " communication skills should be introduced and developed early" thus [4] states that progressive learning outcomes as the important steps to improve the students'perceptions of the English communication. Finally, this study revealed that the students had positive perceptions on English communication practice in the Sunda strait Traffic Separation Scheme (TSS) scenarios.

\section{References}

[1] Alam and Uddin. Improving English Oral Communication Skills of Pakistani Public School's Students. International Journal of English Language Teaching. 2013 Vol. 1, No. 2, pp 17-36._5

[2] Chan, V.'Teaching Oral Communication in Undergraduate Science: Are We Doing Enough and Doing It Right?". Journal of of Learning Design. 4 (3). 2011: 71:79._6

[3] Greenberg and Baron. Behavior in Organizations. New York: Mcgraw-Hill: 1999._4

This paper is presented in The $4^{\text {th }}$ International Conference on Maritime Education and Training 
[4] Knight, P.T. "Complexity and Curriculum: A Process Approach to Curriculummaking." Teaching in Higher Education 6 (3). 2001: 369-381._7

[5] Kotler and Ketler. Prinsip-Prinsip Persepsi. PT. Indeks Kelompok Gramedia: Yogyakarta: 1999._3

[6] Logie, Catherine. "Thinking globally, acting locally-Implementation of IMO Model Course 3.17: Maritime English". Paper presented at the Eleventh IMLA international Workshop on Maritime English, Varna Bulgaria. 2001_2

[7] Sunaryo, Antoni and Tri. IMPLEMENTATION OF TRAFFIC SEPARATION SCHEME FOR PREVENTING ACCIDENT ON SUNDA STRAIT. International Journal of Technology · December 2015_1 